\title{
Factors Affecting Credit Risk: An Empirical Study of the Jordanian Commercial Banks
}

\author{
Dr. Abedalfattah Zuhair Al-abedallat
}

Faculty of Business and Finance,

The World Islamic Sciences \& Education University, Amman, Jordan

doi: 10.19044/esj.2016.v12n34p307 URL:http://dx.doi.org/10.19044/esj.2016.v12n34p307

\begin{abstract}
The problem of the study shows that various Banks suffer from many types of banking risks. This has significantly affected banks' profits. The credit risk is considered to be the major risks to commercial banks. Also, the study aimed to identify the various factors that are affecting credit risk. The study findings shows that there is significant statistical impact of the factors (the efficiency of workers in the banking credit, the instructions of the Central Bank, and the credit policy of the bank) on the credit risks in the Jordanian commercial banks. The study rejected the null hypotheses and accepted the alternative hypotheses for the main hypotheses and three subhypothesis. The study recommended that the central bank should increase their oversight on the credit granted by the commercial banks. Also, the commercial banks should establish a department of risk management, and make diversification in the credit facilities so as to reduce the credit risk.
\end{abstract}

Keywords: Credit Risk, Credit Policy, the Central Bank instructions, Jordanian Commercial Bank

\section{Introduction}

Consequently, banks play a great role in any economy. The financial market is mirror to the economy where we, through their studies, can pass a verdict on the economy. Also, the credit facilities and deposits which are considered from traditional services to the banks, work as an intermediary between units of the surplus and deficit.

However, all kinds of direct and indirect credit facilities are the most profitable investment to the bank. In this case, the banks are running and investing the depositors' money on credit facilities which are an important source of revenue for the bank.

Furthermore, the Banks suffer from many types of banking risks and this has significantly affected the banks' profits. The credit risk is considered 
as the major risks to commercial banks. This risk is based on the client's obligation to pay the amount borrowed. The problem of the study is the Factors affecting the credit risk which are: the efficiency of workers in the banking credit, the instructions of the Central Bank, and the credit policy of the bank in commercial banks. In addition, the study seeks to identify those factors and the most important solutions to that problem. Also, it makes appropriate recommendations.

\section{Study Objectives}

The objective of the study is to answer the following questions:

1. What is the size of the credit facilities provided by the Jordanian commercial banks?

2. What is the importance of the credit facilities?

3. What is the role played by the efficiency of workers in the banking credit to reduce the size of the credit risk?

4. What is the role of Instructions of the Central Bank in influencing the credit risk?

5. Is there an effect of the credit policy of the Banks on the credit risk?

3. Study Framework and Hypotheses

To study the Factors that are affecting the credit risk, the following model was constructed as shown below:

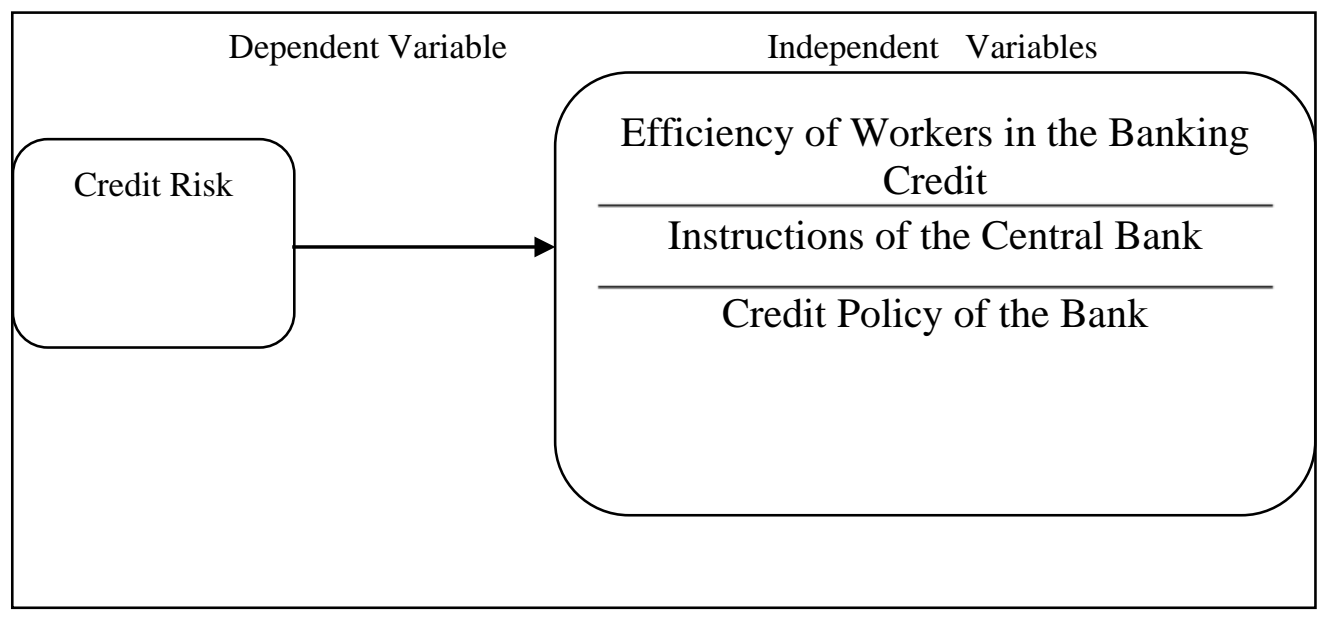

Figure 1. Conceptual Framework

In studying the Factors that affects the credit risk in the Jordanian Commercial Banks, the following hypothesis was built:

H01 - There is no significant statistical impact of the Factors (the efficiency of workers in the banking credit, the instructions of the Central Bank, and the credit policy of the bank) on the credit risks at $\mathrm{p} \leq 0.05$. 
Therefore, it consists of the followings sub-hypothesis:

H01-1: There is no significant statistical impact of the Factors (Efficiency of workers in the banking credit) on the credit risks at $\mathrm{p} \leq 0.05$.

H01-2: There is no significant statistical impact of the Factors (Instructions of the Central Bank) on the credit risks at $\mathrm{p} \leq 0.05$.

H01-3: There is no significant statistical impact of the Factors (Credit policy of the bank) on the credit risks at $\mathrm{p} \leq 0.05$.

\section{The Theoretical Framework}

The number of banks in Jordan is twenty-six. They are broken down as follows: 13 Jordanian commercial banks, 9 foreign commercial banks, and three Jordanian Islamic banks which are the Islamic international Arab bank, Jordanian Dubai Islamic bank, and the Jordanian Islamic bank. An example of foreign Islamic bank is the AL-Rajhi bank (Annual report of the Association of Banks in Jordan in 2014).

Subsequently, the Banks invest most of their funds in the credit facilities, which can be divided into:

1- Direct Credit Facilities: This includes the payment of a sum of money to the customer with the right to demand repayment in the future with benefits and commissions. An example of it includes loans and advances, and the current debtor and Credit Cards. Therefore, it is possible to grant credit facilities as short-term, medium-term, or long-term. Also, the customer should provide the guarantees as a condition to get him credit.

2- Indirect Credit Facilities: This refers to a pledge or security issued by the Bank. Examples include: guarantees and letters of credit, which plays an important role in international trade and in import and export (Alrgebat, 2014).

The Central Bank of Jordan was established in 1964. Thus, the bank which manages monetary policy and oversees the monetary and banking sector in Jordan, aims to maintain monetary stability in the kingdom. It also aims at ensuring the convertibility of the Jordanian Dinar.

The central bank also offers loans and advances to banks in addition to doing the process of rediscount of the commercial papers. However, it plays this role from his position as father of the banks, thus providing liquidity to commercial banks when needed. It also has control over the work of banks through legislation and periodic reports, which banks provide the central bank to ensure a suitable use of the bank's funds (Ramadan \& Goda, 2013).

The central bank controls the banks through the law of banks that regulate the relationship of the banks with others and the conditions for the activities of banks. In the case of violation of the provisions of the Bank Law, it is possible that the central bank would impose sanctions such as 
alarm or reduce the size of the credit facilities. It is business that is not permitted under the Banking Law in Jordan: no bank credit may be provided to a person over the limit of the central bank (Trad \& abbad, 2009).

Credit risk occurs when the customer does not pay the premiums, interest, or part of it at the defined time in a credit agreement. However, there are ways to reduce credit risks, including:

1. Efficiency of Workers in the Banking Credit

The bank should interest workers in the banking credit and train them and especially with regard to financial analysis of the client and the use of computers in the analysis process. In addition, it should also provide physical and moral incentives to them, as well as the necessity of the presence of department to follow, and collection that have qualified workers. Also, the bank must have department responsible for the management of banking risk.

2. Diversification of bank credit granted by the length of time, and depending on the purpose and the banking sector to reduce credit risk.

3. Insurance of the guarantees and the lives of borrowers through various insurance companies.

Subsequently, the studying of the credit of customers is based on the five elements of the resolution, a credit-based model 5Cs which are:

\section{Character}

Character means the client's reputation or client's desire to pay. Hence, it is possible to identify it through the study of the history of the client as they interact with the bank. In addition, it also has to do with his reputation in the market in which he operates.

\section{Capacity}

It is the client's ability to get a loan. The bank can study the legal form of the company and the financial analysis of the financial statements, and the cash flows for the client. Therefore, the aim of this analysis is to know the customer's ability to repay the loan.

\section{Capital}

It is one of the elements of the credit decision, which relies on the study of the capital of the company size, sales, cash flows, and market share of the customer.

\section{Collateral}

The second source of repayment after the cash flows and the bank must obtain guarantees from customers to reduce credit risks. Thus, there are many kinds of collateral such as: cash insurance, personal sponsorship, land, cars, buildings, and securities. 


\section{Conditions}

It is one of the elements of the credit decision, which relies on the study of the economic and political conditions. The bank, in the case of a recession, reduces the rate at which they grant credit. On the other hand, they make the process of giving grants rigorous such as raising interest rates; thus, in the case of inflation, the bank is expanding in the granting of credit facilities (Musa et al., 2012).

Consequently, each bank selects credit policy that does not conflict with the central bank's instructions. Thus, it helps them to reduce the size of the credit risk that relates to the credit of the bank policy which includes the following:

1. The Geographic Area: Here, the bank determines the geographic area where the Bank operates and it depends on many factors which includes; the size of the resources available to the bank and the amount of competition with other banks.

2. Determine the Types of Credit: The bank determine the types of credit that deal with the customers and it gives interest with the diversification of the credit.

3. Determine the Acceptable Collateral to the Bank: The guarantees consider the second defense of the credit after the cash flows.

4. The Maturity: The bank should determine the period of various credit.

5. The Ceiling of Credit: The bank should specify the upper ceilings of extended credit to customers.

6. The guide of the procedures and the required documents for the granting of credit.

7. Interest and other costs of credit rates.

8. Procedures of the credit and follow-up and assess credit risk.

(Al-Zubaidi, 2002) Jordan.

Furthermore, Table 1 shows the growth in the deposits at banks in

Table 1. The growth in the deposits at banks in Jordan

\begin{tabular}{|c|c|}
\hline Banking Deposits( $\mathrm{m})$ & Year \\
\hline 11564.100 & 2004 \\
\hline 13119.300 & 2005 \\
\hline 14591.900 & 2006 \\
\hline 15988.100 & 2007 \\
\hline 18102.600 & 2008 \\
\hline 20298.400 & 2009 \\
\hline 22504.800 & 2010 \\
\hline 24377.900 & 2011 \\
\hline 24969.700 & 2012 \\
\hline 29159.92 & 2013 \\
\hline 31942.122 & 2014 \\
\hline
\end{tabular}

(The Central Bank of Jordan, 2014) 


\section{Previous Study}

There are many studies that addressed the factors affecting the credit risk. Therefore, the most important of these studies are:

1 - Study (Othman, 2009) Entitled "Management of Assets and Liabilities with the Conventional Banks and Islamic Banks: A Comparative Study”

The study aimed to assess the liquidity management and profit, and the risk among a sample of Islamic commercial banks in Jordan. It studies the evaluation of the assets and liability management at these banks. The study found a correlation relationship between the assets and liabilities of banks in the sample, and also shows the diversity of the banks in the short and long-term funding.

The study recommended that there is the need to give more long-term financing to increase profits and to contribute to the economic development in the Kingdom.

2- Study (Sheikhli, 2012) Entitled "Key Factors Specific to the Decision of Bank Credit to Commercial Banks of Jordan”

The purpose of the research is to study the factors affecting the bank's decision of banking credit. This includes the financial situation of the client, the personal characteristics of the client, and policy credit of the bank. Here, the researcher used the descriptive and analytical approach. Therefore, the study concluded that there is an important role of the previous factors on the decision of credit in the Jordanian commercial banks. Also, the variable of Pattern credit policy has the strongest influence. As a result, the following was recommended: the importance of focusing on the workers facing credit risk based on the elements of the financial situation of the client, and the attention to financial ratios in the financial analysis to reduce credit risk.

3-Study (Siam et al., 2011) Entitled: "The Utilizing of Financial Analysis in Rationalizing Decision of Granting Credit Facilities

The research aims to study the importance of the use of financial indicators (horizontal analysis, vertical analysis, and financial ratios) based on the credit decision-making and the extent of its use to predict financial failure models. It shows their importance in the decision-making credit right, as well as identifies the most important determinants that hinder the use of these indicators.

The study concluded that the use of these methods in the analysis leads to the knowledge of the real situation of the borrower and its ability to repay and reduce risks. The study found that the liquidity ratios are the most important ratios used together with the customer's credit analysis and decision bitumen credit.

4-Study (Maitah et al., 2012) Entitled “The Utilizing of Financial Analysis in Credit Decision in Palestinian Commercial Banks 
The study aimed to identify the extent of knowledge and use of employees in credit in Palestinian commercial banks financial indicators in the analysis. This is aimed to make the decision of credit, and to identify the obstacles to using methods of financial analysis when considering a credit request from the customer. The study findings show that the bank should expand the use of the methods of financial analysis of all kinds (horizontal analysis, vertical analysis, financial ratios). This, however, leads to making the right decision where credit is recognized as the customer's ability to repay through the identification of cash flows for the client.

5-Study (Kortell \& Rezzig, 2007) Entitled "Management Risk of Investment Loans in the Algerian Commercial Banks

The research aims to study the credit risk in the Algerian banks, and the various ways to reduce these risks. The study found the presence of a group of factors that lead to the credit risk such as reasons resulting from general risks such as economic conditions that banks cannot control with it. Another reason is related to not keeping a pace with technological development, and there are reasons related to the borrower himself.

Subsequently, the researcher found that there is need to measure the credit risk and the bank through various models to predict financial failure, and to follow-up customer in the field of credit until full settlement.

6- Study (Gehad, 2012) Entitled "Management Credit risk in Commercial Banks”

The study aimed to find out about the risk management of credit in commercial banks in Algeria. It shed light on the importance of the hedge against the risk of credit in the banks. To identify the basic principles of risk management, the study reached out to the banks in Algeria. Thus, it interestingly studies the rules and regulations, general economic climate, and also the attention of banks in Algeria by the guarantees as the first line of defense for the bank and not the cash flow for the customer.

The study recommended that the decision of credit when the client of the credit facilities was granted based on cash flows for the client and reputation shows that the ability of the customer to pay, which is the primary source of repayment, is not a guarantee.

7- Study (Khalidi, 2010) Entitled "Influence of Internal Factors on the Return of Loans and Credit Facilities Portfolio in Iraqi Commercial Banks

The study aimed to identify the internal factors that affect the yield of the loan portfolio and credit in Iraqi banks. This, however, is in a bid to enhance its positive impact. The study found a positive relationship with the return of the loan portfolio and bank credit (dependent variable) with the size of the bank, the adequacy capital and the liquidity of the bank, the spending on advertising, and the age of the bank. 
Furthermore, the study also found that there is an inverse relationship between the return of the portfolio and the rate of employment of deposits in the credit.

\section{Methodology of the Study}

For the purposes of testing the hypotheses of the study and in answering the questions of this study, the study relied on descriptive and analytic method, as well as field study. With regard to the descriptive side, the study gave an accurate picture of the Factors that affects the credit risk. However, through previous studies, as for the side of the field, the study relied on a questionnaire designed in order to collect the necessary data to test hypotheses.

The population of the study represents the Jordanian commercial in the Jordan, which offers various banking services to the customers. Here, the study distributed a questionnaire to obtain information about the study. Also, the sample of the study is the upper and middle level of employees in the Jordanian Commercial Banks been distributed as shown below:

Table 2. Distribution of the Jordanian commercial banks

\begin{tabular}{|c|c|c|c|}
\hline Bank & Assets & Rank & $\begin{array}{c}\text { The ratio of total } \\
\text { assets of the Bank }\end{array}$ \\
\hline Arab Bank & 8726 & 1 & $20.16 \%$ \\
\hline Jordan Ahli Bank & 2120 & 5 & $4.9 \%$ \\
\hline Cairo Amman Bank & 1885.22 & 6 & $4.36 \%$ \\
\hline Bank of Jordan & 1859.6 & 7 & $4.3 \%$ \\
\hline The Housing Bank & 6508.6 & 2 & $15.04 \%$ \\
\hline Jordan Kuwait Bank & 2369 & 3 & $5.47 \%$ \\
\hline Arab Jordan Investment Bank & 1632 & 9 & $3.77 \%$ \\
\hline Jordan Commercial Bank & 1096.41 & 10 & $2.53 \%$ \\
\hline Invest Bank & 788.62 & 13 & $1.8 \%$ \\
\hline Arab Banking Corp./Jordan & 1083 & 11 & $2.5 \%$ \\
\hline Union Bank & 2239.69 & 4 & $5.17 \%$ \\
\hline Society General Bank & 867.13 & 12 & $2 \%$ \\
\hline Capital Bank & 1825.47 & 8 & $4.22 \%$ \\
\hline
\end{tabular}

(The Association of Banks in Jordan, 2014)

Table 3. Distribution of questionnaire

\begin{tabular}{|c|c|c|}
\hline Bank & $\begin{array}{c}\text { No. of } \\
\text { questionnaire }\end{array}$ & $\begin{array}{c}\text { No. of obtained } \\
\text { questionnaire }\end{array}$ \\
\hline Arab Bank & 55 & 50 \\
\hline Jordan Ahli Bank & 17 & 17 \\
\hline Cairo Amman Bank & 18 & 17 \\
\hline Bank of Jordan & 11 & 9 \\
\hline The Housing Bank & 45 & 43 \\
\hline Jordan Kuwait Bank & 16 & 16 \\
\hline Arab Jordan Investment Bank & 11 & 11 \\
\hline Jordan Commercial Bank & 9 & 9 \\
\hline
\end{tabular}




\begin{tabular}{|c|c|c|}
\hline Invest Bank & 8 & 8 \\
\hline Arab Banking Corp./Jordan & 8 & 8 \\
\hline Union Bank & 16 & 16 \\
\hline Society General Bank & 6 & 6 \\
\hline Capital Bank & 10 & 10 \\
\hline
\end{tabular}

The study designed a questionnaire to solicit the views of an employee of Islamic banks about the study on a Likert scale. Therefore, the study distributed 230 questionnaires, and recovered 220 of those questionnaires. In addition, the percentage is $95.6 \%$.

A tool of the study (a questionnaire) has been showed on a group of arbitrators (6 experts). This is aimed to ensure the veracity of content resolution and good drafting, and the representation of the subject accurately. Also, the reliability coefficient of the questionnaire according to the coefficient (Cronbach alpha) is (85\%) through the statistical analysis of the study's sample.

\section{The Results of Hypothesis Testing Descriptive Statistics}

This section contains the results of the study aimed to know the Factors that affects the credit risk. It includes a description of the personality variables for members of the study sample. Thus, the study used the program of statistical analysis (SPSS) to extract the averages, arithmetic mean, and standard deviations of the paragraphs of the questionnaire. The following is a presentation of the demographic variables according to Table 4.

Table 4. Distribution of study sample according to demographic variables

\begin{tabular}{|c|c|c|}
\hline Variable & Frequency & Percentage $\%$ \\
\hline 1- Gender & & $73 \%$ \\
\hline Male & 161 & $27 \%$ \\
\hline Female & 59 & $7 \%$ \\
\hline 2- Job site & 16 & $6 \%$ \\
\hline Manager Department & 13 & $64 \%$ \\
\hline $\begin{array}{c}\text { Assistant Manager of the } \\
\text { Department }\end{array}$ & 141 & $23 \%$ \\
\hline Manager Branch & 50 & $15 \%$ \\
\hline Head Department & & $72 \%$ \\
\hline 3-Academic Qualifications & 33 & $13 \%$ \\
\hline Graduates (Ph.D. or Master) & 158 & $3 \%$ \\
\hline Bachelor's & 29 & $6 \%$ \\
\hline Diploma or less & & $79 \%$ \\
\hline 4-Years of experience & 14 & $12 \%$ \\
\hline 5 years or less & 174 & 25 \\
\hline More than 5 to10 years & & \\
\hline More than 10 to15 years & & \\
\hline More than 15 years & & \\
\hline
\end{tabular}




\section{Results of Testing the Hypotheses Descriptive Statistics}

The result of the answers to the questions of the hypothesis is shown in the table 5 below.

Table 5. The results of the answers to the questions of the hypothesis

\begin{tabular}{|c|c|c|c|}
\hline Number & $\begin{array}{c}\text { Paragraph } \\
\text { The efficiency of Workers in the Banking } \\
\text { Credit }\end{array}$ & $\begin{array}{c}\text { Arithmetic } \\
\text { Averages }\end{array}$ & $\begin{array}{c}\text { Standard } \\
\text { Deviations }\end{array}$ \\
\hline $1-$ & $\begin{array}{c}\text { The workers in the banking credit undergo the } \\
\text { necessary training courses }\end{array}$ & 3.33 & .91 \\
\hline $2-$ & $\begin{array}{c}\text { The workers in the banking credit use the } \\
\text { financial analysis of the client before making } \\
\text { a credit decision. }\end{array}$ & 3.69 & .49 \\
\hline $3-$ & $\begin{array}{c}\text { Employees in bank credit pay attention to } \\
\text { studying the cash flow for the customer as the } \\
\text { primary source of repayment. }\end{array}$ & 3.51 & 0.81 \\
\hline $4-$ & $\begin{array}{c}\text { Studying for customer credit based on the } \\
\text { study of the elements of a credit decision } \\
\text { credit as in the model 5Cs. }\end{array}$ & 3.34 & .76 \\
\hline 5- & $\begin{array}{c}\text { Employees in bank credit using modern } \\
\text { technology in relation to the credit analysis } \\
\text { for the client in making a credit decision. }\end{array}$ & 3.44 & \\
\hline Total & $\quad$ & 3.462 & \\
\hline
\end{tabular}

The researcher notes from the previous table 5 include paragraphs that test the first hypothesis. It shows that the Arithmetic Averages ranged between 3.33-3.69, and the highest average is paragraph No. 2, which states that "The workers in the banking credit use the financial analysis of the client before making a credit decision.” In general, all the averages were higher than Class 3, and the overall average of the paragraph is 3.462.

Table 6 . The results of the answers to the questions of the hypothesis

\begin{tabular}{|c|c|c|c|}
\hline Number & $\begin{array}{l}\text { Paragraph } \\
\text { The instructions of the Central bank }\end{array}$ & $\begin{array}{l}\text { Arithmetic } \\
\text { Averages }\end{array}$ & $\begin{array}{c}\text { Standard } \\
\text { Deviations }\end{array}$ \\
\hline 6- & The central bank makes periodic control on bank credit. & 3.33 & 0.98 \\
\hline 7- & The Central Bank sets certain limits on bank credit. & 3.56 & 0.78 \\
\hline 8- & $\begin{array}{l}\text { The Commercial Bank provides the Central Bank with } \\
\text { reports of bank credit periodically. }\end{array}$ & 3.24 & .56 \\
\hline 9- & $\begin{array}{l}\text { The Central Bank sets a ceiling specified, and which } \\
\text { might not be exceeded with regard to the granting of } \\
\text { credit per customer. }\end{array}$ & 3.31 & .74 \\
\hline $10-$ & $\begin{array}{l}\text { The control by the central bank on bank credit reduces } \\
\text { the volume of bad debts. }\end{array}$ & 3.45 & .81 \\
\hline $11-$ & $\begin{array}{l}\text { The Central Bank cooperates with banks with respect to } \\
\text { providing them with information about the customer } \\
\text { who is committed to paying to reduce the risk Credit. }\end{array}$ & 3.81 & 69 \\
\hline Total & & 3.45 & \\
\hline
\end{tabular}


The researcher notes from the previous table 6 include paragraphs that test the first hypothesis. It shows that the Arithmetic Averages ranged between 3.24-3.81, and the highest average is paragraph No. 11, which states that "The Central Bank cooperates with banks with respect to providing them with information about the customer who is committed to paying to reduce the risk Credit.” In general, all averages were higher than Class 3, and the overall average of the paragraph is 3.45 .

Table 7. The results of the answers to the questions of the hypothesis

\begin{tabular}{|c|c|c|c|}
\hline Number & $\begin{array}{c}\text { Paragraph } \\
\text { The credit policy of the bank }\end{array}$ & $\begin{array}{c}\text { Arithmetic } \\
\text { Averages }\end{array}$ & $\begin{array}{c}\text { Standard } \\
\text { Deviations }\end{array}$ \\
\hline $12-$ & $\begin{array}{c}\text { The Bank guide of policies and procedures } \\
\text { available to all workers in the banking credit. }\end{array}$ & 3.45 & .67 \\
\hline $13-$ & $\begin{array}{c}\text { The Bank cares about the existence of credit risk } \\
\text { management and provides it with qualified staff. }\end{array}$ & 3.75 & .46 \\
\hline $14-$ & $\begin{array}{c}\text { The credit policy of the bank is built on the basis } \\
\text { of diversification in terms of credit type, duration, } \\
\text { and granted amounts and accepted guarantees. } \\
\text { The credit policy of the bank focuses on the credit } \\
\text { study of the customers in terms of the ability to } \\
\text { pay and a reputation as a basis for decision Credit. }\end{array}$ & 3.47 & 3.64 \\
\hline $16-$ & $\begin{array}{c}\text { The presence of clear credit policy of the bank } \\
\text { reduces the volume of bad debts. }\end{array}$ & 3.33 & .67 \\
\hline Total & & 3.528 & \\
\hline
\end{tabular}

The researcher notes from the previous table 7 include paragraphs that test the first hypothesis. It shows that the Arithmetic Averages ranged between 3.33-3.75, and the highest average is paragraph No. 14, which states that "The presence of clear credit policy of the bank reduces the volume of bad debts.” In general, all averages were higher than Class 3, and the overall average of the paragraph is 3.528 .

Table 8 . The results of the answers to the questions of the hypothesis

\begin{tabular}{|c|c|c|c|}
\hline Number & $\begin{array}{c}\text { Paragraph } \\
\text { Credit Risk }\end{array}$ & $\begin{array}{c}\text { Arithmetic } \\
\text { Averages }\end{array}$ & $\begin{array}{c}\text { Standard } \\
\text { Deviations }\end{array}$ \\
\hline $17-$ & $\begin{array}{c}\text { Study of the elements of credit decision before the } \\
\text { grant reduces the risk of credit Size. }\end{array}$ & 3.31 & .67 \\
\hline $18-$ & $\begin{array}{c}\text { The focus on cash flows for the client as a } \\
\text { principal source of repayment reduces the credit } \\
\text { risk. }\end{array}$ & 3.34 & .36 \\
\hline $19-$ & $\begin{array}{c}\text { The banking supervision of the Central Bank on } \\
\text { extended credit by banks reduces the risks of } \\
\text { credit. }\end{array}$ & 3.56 & .89 \\
\hline $20-$ & $\begin{array}{c}\text { The bank's commitment to the instructions of the } \\
\text { central bank lowers the risk of credit. }\end{array}$ & 3.64 & .42 \\
\hline $21-$ & $\begin{array}{c}\text { The presence of a clear credit policy of the bank } \\
\text { reduces the credit risk. }\end{array}$ & 3.73 & 1.67 \\
\hline $22-$ & $\begin{array}{c}\text { Establishment of credit policy on the basis of the } \\
\text { diversification in the field of credit type and } \\
\text { duration, and it reduces the amount of credit risk. }\end{array}$ & 3.78 & \\
\hline Total & & 3.56 & \\
\hline
\end{tabular}


The researcher notes from the previous table 8 include paragraphs that test the first hypothesis. It shows that the Arithmetic Averages ranged between 3.31-3.78, and the highest average is paragraph No. 22, which states "Establishment of credit policy on the basis of the diversification in the field of credit type and duration, and it reduces the amount of credit risk." In general, all averages were higher than Class 3, and the overall average of the paragraph is 3.56 .

\section{Test of the First Hypotheses}

In this section, the study researcher presented an analysis of the results of the study hypotheses. As mentioned before, for testing Ho1, the researcher also use a sample of an employee of the Jordanian commercial banks. However, the following subsections provide an analysis of the results of the hypotheses testing at the total sample level.

To test the first hypothesis, Multiple Linear Regression model was used. Thus, the result is shown in table 9 .

H01 - There is no significant statistical impact of the Factors (the efficiency of workers in the banking credit, the instructions of the Central Bank, and the credit policy of the bank) on the credit risks at $\mathrm{p} \leq 0.05$.

Table 9. Result of the multiple linear regression test

\begin{tabular}{|c|c|c|c|c|}
\hline $\begin{array}{c}\text { Dependent } \\
\text { Variable }\end{array}$ & $\begin{array}{c}\text { Independent } \\
\text { Variables }\end{array}$ & $\begin{array}{c}\text { Regression } \\
\text { Coefficient B }\end{array}$ & $\begin{array}{c}\text { Value of T } \\
\text { calculated }\end{array}$ & Sig. \\
\hline Credit risk & $\begin{array}{c}\text { The efficiency of } \\
\text { workers in the } \\
\text { banking credit }\end{array}$ & 0.135 & 2.02 & 0.001 \\
\hline & $\begin{array}{c}\text { Instructions of the } \\
\text { Central Bank }\end{array}$ & 0.112 & 1.22 & 0.002 \\
\hline & $\begin{array}{c}\text { Credit policy of the } \\
\text { bank }\end{array}$ & 0.012 & 1.45 & 0.003 \\
\hline & $\mathrm{R}=0.89 \quad \mathrm{R} 2=0.792 \quad \mathrm{~F}=50.22$ & Sig. $=0.000$ & \\
\hline
\end{tabular}

From the table 9, there is an impact of independent variables on the dependent variable and this refers to the good relation between Affecting Factors and financing of small projects. The value of Sig. is less than 0.005 and the value of Pearson correlation $(\mathrm{R})=0.89$. This, however, refers to the rejection of the null hypothesis and it accepts the alternative hypothesis.

To test the sub-hypothesis in no (1), a simple linear regression model was used. Therefore, the result is as shown in table 10.

H01-1 - H01-1: There is no significant statistical impact of the Factors (Efficiency of workers in the banking credit) on the credit risks at $\mathrm{p} \leq$ 0.05 . 
Table 10. Result of the simple linear regression test

\begin{tabular}{|c|c|c|c|c|}
\hline $\begin{array}{c}\text { Independent } \\
\text { Variable }\end{array}$ & Dependent Variable & $\begin{array}{c}\text { Regression } \\
\text { Coefficient B }\end{array}$ & $\begin{array}{c}\text { Value of T } \\
\text { calculated }\end{array}$ & Sig. \\
\hline Credit risk & $\begin{array}{c}\text { Efficiency of } \\
\text { workers in the } \\
\text { banking credit }\end{array}$ & 0.134 & 1.60 & 0.003 \\
\hline $\mathrm{R}=0.87$ & $\mathrm{R} 2=0.7569$ & $\mathrm{~F}=54.1$ & Sig. $=0.003$ \\
\hline
\end{tabular}

As shown in table 10, there is a significant impact of the independent variable on the dependent variable and this refers to the good relation between the Banking obstacles and the financing of small projects. The value of Sig. is less than 0.05 and the value of Pearson correlation $(R)=0.87$. This, however, refers to the rejection of the null hypothesis and it accepts the alternative hypothesis.

To test the sub-hypothesis in no (2), a simple linear regression test was used. Therefore, the result is as shown in Table 11.

H01-2: There is no significant statistical impact of the Factors (Instructions of the Central Bank) on the credit risks at $\mathrm{p} \leq 0.05$.

Table 11. Result of the simple linear regression test

\begin{tabular}{|c|c|c|c|c|}
\hline $\begin{array}{c}\text { Independent } \\
\text { Variable }\end{array}$ & Dependent Variable & $\begin{array}{c}\text { Regression } \\
\text { Coefficient B }\end{array}$ & $\begin{array}{c}\text { Value of T } \\
\text { calculated }\end{array}$ & Sig. \\
\hline Credit risk & $\begin{array}{c}\text { Instructions of the } \\
\text { Central Bank }\end{array}$ & 0.131 & 2.11 & 0.002 \\
\hline $\mathrm{R}=0.85$ & $\mathrm{R} 2=0.722$ & $\mathrm{~F}=47.1$ & \multicolumn{2}{|c|}{ Sig. $=0.002$} \\
\hline
\end{tabular}

From the table 11, there is a significant impact of the independent variable on the dependent variable. This refers to the good relation between the Obstacles of the small projects on the financing or small projects. The value of Sig. is less than 0.05 and the value of Pearson correlation $(\mathrm{R})=0.85$. This, however, refers to the rejection of the null hypothesis and it accepts the alternative hypothesis.

To test the sub-hypothesis in no (3), a simple linear regression test was used. Therefore, the result is as shown in table 12 .

H01-3: There is no significant statistical impact of the Factors (Credit policy of the bank) on the credit risks at $\mathrm{p} \leq 0.05$.

Table 12. Result of the simple linear regression test

\begin{tabular}{|c|c|c|c|c|}
\hline $\begin{array}{c}\text { Independent } \\
\text { Variable }\end{array}$ & $\begin{array}{c}\text { Dependent } \\
\text { Variable }\end{array}$ & $\begin{array}{c}\text { Regression } \\
\text { Coefficient B }\end{array}$ & $\begin{array}{c}\text { Value of T } \\
\text { calculated }\end{array}$ & Sig. \\
\hline Credit risk & $\begin{array}{c}\text { Credit policy of } \\
\text { the bank }\end{array}$ & 0.165 & 1.70 & .003 \\
\hline $\mathrm{R}=0.89$ & $\mathrm{R} 2=0.792$ & $\mathrm{~F}=64.1$ & \multicolumn{2}{c|}{ Sig. $=0.003$} \\
\hline
\end{tabular}


From the Table 12, there is a significant impact of the independent variable on the dependent variable. This refers to the good relation between Governmental obstacles on the financing of small projects. The value of Sig. is less than 0.05 and the value of Pearson correlation $(\mathrm{R})=0.89$. Therefore, this leads to the rejection of the null hypothesis and it accepts the alternative hypothesis.

\section{Summary and Concluding Remarks}

This study attempts to investigate the impact of the Factors (the efficiency of workers in the banking credit, the instructions of the Central Bank, and the credit policy of the bank) on the credit risks at $\mathrm{p} \leq 0.05$, and the results (findings).

1. There is a significant statistical impact of the factors (the efficiency of workers in the banking credit, the instructions of the Central Bank, and the credit policy of the bank) on the credit risks in the Jordanian commercial banks.

2. The study rejected the null hypotheses and accepted the alternative hypotheses for the main hypotheses.

3. The study rejected the null hypothesis and accepted the alternative hypothesis for the three sub-hypothesis. 4. There is a good statistical relationship between the factors (the efficiency of workers in the banking credit, the instructions of the Central Bank, and the credit policy of the bank) and the credit risks in the Jordanian commercial banks.

\section{Recommendations}

The study has recommended the following:

1. The central bank should increase oversight on the credit granted by the commercial bank.

2. The commercial banks should establish a department of risk management.

3. The commercial banks make diversification in the credit facilities in order to reduce the credit risk.

4. The commercial banks should have a hedge against insurance with insurance companies.

\section{References:}

1. Alrgebat Ghazi (2014). Banks and financial institutions and specialized. ( $1^{\text {st }}$ ed.), , Amman Jordan: Dar Wael for Publication.

2. Al-Zubaidi \& Mahmoud Hamza (2002). The banking and credit analysis, credit management, Amman, Jordan: organization Warraq for Publishing and Distribution. 
3. Association of Banks in Jordan (2014). Annual report of the Association of Banks in Jordan in 2014. Retrieved from: http://www.abj.org.jo/en-us/annualreports.aspx

4. Central Bank of Jordan (2014). Annual Report of the Central Bank of Jordan in 2014. Retrieved from: http://www.cbj.gov.jo/

5. Gehad hefian (2012). Management of credit risk in commercial banks operating in Ouargla in Algeria.(published Master's thesis). kasdi merbah Ouargla University, Algeria

6. Khalidi Hamad Abdul-Hussein Radi (2010). Influence of internal factors on the return of loans and credit facilities portfolio in Iraqi commercial banks. Iraqi Journal of Management Sciences, No. 24.

7. Kortell Fred \& Rezzig Kamal (2007). Management risk of investment loans in the Algerian commercial banks: paper presented at Fifth Annual Scientific Conference of the University of Philadelphia, Amman, Jordan, 2007: the University of Philadelphia.

8. Maitah Mansour, Zeda Khalid \& Galalh abudeltef.(2012). The utilizing of financial analysis in credit decision in Palestinian commercial banks. Journal of Money, Investment and Banking , 24(12).

9. Musa Shukairy Nuri, Noor Mahmoud Ibrahim Haddad, Mohammad Wasim \& Theeb Susan Samir (2012). Risk management ( $1^{\text {st }}$ ed .). Amman, Jordan: Dar almasera for publication and distribution.

10. Othman Omar Mohamed (2009). The assets and liabilities of the conventional banks and Islamic banks and administration.( unpublished dissertation). University of Damascus, Syria.

11. Ramadan Ziad \& Goda Mahfouz (2013). Contemporary trends in bank management $\left(4^{\text {th }}\right.$ ed.). Amman, Jordan: Dar Wael for publication.

12. Sheikhli Hadeel Ibrahim Amin (2012). Key factors specific to the decision of bank credit to commercial banks of Jordan (published Master's thesis). The Middle East University, Amman, Jordan.

13. Siam walid, Zakaria Khrawish, Husni \& Ali Al-dass abdalla (2011). The utilizing of financial analysis in rationalizing decision of granting credit facilities. International Research Journal of Finance and Economics, 69(11).

14. Trad Ismail Ibrahim \& abbad Jumna Mahmoud (2009). The banking and financial legislation in Jordan ( $4^{\text {th }}$ ed.). Amman, Jordan: Dar Wael for publication. 